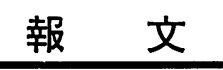

\title{
サフラワー油一鉄板系における溶存水と溶出鉄 の相関関係
}

\author{
高砂子 昌 久・高 岡京 \\ 武蔵工業大学 (東京都世田谷区玉堤 1-28-1) \\ The Relation between Dissolved Water and Iron \\ from the Iron Plate in Safflower Oil \\ Masahisa TAKASAgo and Kyo TAKAOKA \\ Department of Chemistry, Musashi Institute of Technology \\ (1-28-1, Tamazutsumi, Setagaya-ku, Tokyo)
}

The dissolution of iron from the iron utensil to the vegetable oil has been studied on using the iron plate and safflower oil with the dissolved water at $180^{\circ} \mathrm{C}$. At this experiment, water was added dropwise to the safflower oil contained the iron plate at $180^{\circ} \mathrm{C}$, and the relation between the amount of dissolved water and dissolved iron in the oil was investigated.

The amount of dissolved water in the oil was $580 \sim 1168 \mathrm{ppm}$ for $1 \sim 3 \mathrm{~h}$ at these conditions. The ratio of physically and chemically adsorbed water on the iron plate was $9.4 \sim 10.7 \%$ of the dissolved water in the oil. On the other hand, the ratio of iron and its oxides on the surface of the plate was $15: 85$ by measurement with ESCA. The ratio of the iron oxide derivative on the plate surface decreased from $81 \%$ to $34 \%$ under the same experimental conditions with $1 \sim 3 \mathrm{~h}$ heating. At the same time, the dissolved amount of iron from the plate in the oil increased from $0.12 \mathrm{ppm}$ to $1.23 \mathrm{ppm}$ for $1 \sim 3 \mathrm{~h}$.

From these results, the dissolution process of iron from the iron plate in the oil was found to be that the iron oxides on the surface of the plate dissolved in the adsorbed water on the plate and then diffused into the oil.

\section{1 緒言}

油脂を使用して調理した時に調理の材料より水が油中 に溶けこみ, これが調理容器より金属の溶出及び油の酸 化を促進する原因となることが考えられる。

油脂の加熱時に調理容器から油への金属の溶出につい ては油中の遊離脂肪酸が原因としているが1)，いずれも 油中の溶存水についての報告は見当たらない。

著者らは先にサフラワー油中への金属の溶出と油中の 溶存水との関係を $20 \sim 50^{\circ} \mathrm{C}$ の範囲内で検討してきた が22,3)， 、ずれも溶存水量が増加するにつれて金属の溶 出量が増えることを見いだした。加熱時においても油中 の溶存水が金属の溶出の原因になるのではないかと考 え, 本実験では鉄製容器中でのサフラワー油を用いた調 理を想定し, 油に鉄板を入れて水を滴下しながら $180^{\circ} \mathrm{C}$ に加熱し油への鉄の溶出と油中の溶存水との関係を検討 した。また，加熱した後の鉄板の表面状態を ESCA を 用いて分析し鉄の溶出量との関係も検討した。

\section{2 実験}

\section{$2 \cdot 1$ 試料}

$2 \cdot 1 \cdot 1$ サフラワー油

市販のサフラワー油をそのまま使用した。油の性状を Table-1 に示した。油中の水分量はカールフィッシャ 一式自動水分計 $\mathrm{AQ}-1$ (平沼産業製) で測定し $226 \mathrm{ppm}$ を得た。

$2 \cdot 1 \cdot 2$ 鉄板

1) 鉄板の前処理

市販の鉄板（厚さ $0.1 \mathrm{~mm}$ ) $10 \mathrm{~mm} \times 15 \mathrm{~mm}$ の直 方形に切り, これをエーテルで洗浄後 $0.1 \mathrm{mmHg}$ の減 圧下で $80^{\circ} \mathrm{C}$ に加熱乾燥して用いた。

2) 鉄板の表面分析

ESCA で鉄の表面を分析した。装置は JESCA-4（日 本電子製）を用い，48〜 $60 \mathrm{eV}$ の範囲で測定した。結果 を Fig.-1 に示した。

$2 \cdot 2$ 加熱サフラワー油中への水分の溶解実験 
Table-1 Characterization of safflower oil.

\begin{tabular}{|c|c|c|c|c|c|c|c|c|}
\hline \multirow[t]{2}{*}{ SV } & \multirow[t]{2}{*}{$I V^{*}$} & \multirow[t]{2}{*}{ POV } & \multirow{2}{*}{$\begin{array}{c}\mathrm{H}_{2} \mathrm{O} \\
(\mathrm{ppm})\end{array}$} & \multicolumn{5}{|c|}{ Fatty acid composition of safflower oil by GLC (wt $\%)$} \\
\hline & & & & $\mathrm{C}_{16}$ & $\mathrm{C}_{18}$ & $\mathrm{C}_{18: 1}$ & $\mathrm{C}_{18: 2}$ & $\mathrm{C}_{18: 8}$ \\
\hline 194.5 & 142.9 & 0.8 & 226 & 8.7 & 2.9 & 15.4 & 69.4 & 3.6 \\
\hline
\end{tabular}

* Wijs method

Conditions of GLC.

Apparatus : GC-6 A (Shimadzu)

Column : $1.5 \mathrm{~m} \times 3 \mathrm{~mm}$ glass column, DEGS $+\mathrm{H}_{3} \mathrm{PO}_{4}$ $(5+1)$, Chromosorb-W 60/80 mesh

Column temp.: $210^{\circ} \mathrm{C}$

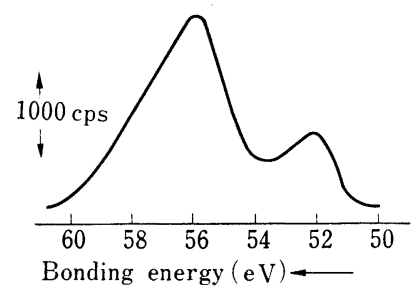

Fig.-1 ESCA spectra of $\mathrm{Fe}_{3 \mathrm{p}}$ of iron and iron oxides on the surface of the iron plate.

サフラワー油 $20 \mathrm{~g}$ 及びガラスウール $1 \mathrm{~g}$ (油の突沸 を防ぐため) を内径 $26 \mathrm{~mm}$ ，深さ $200 \mathrm{~mm}$ の試験管に 入れて $180^{\circ} \mathrm{C}$ に加熱した。室温より $180^{\circ} \mathrm{C}$ に昇温する のに $16 \mathrm{~min}$ かかったが, この間の溶存水量の減少はほ

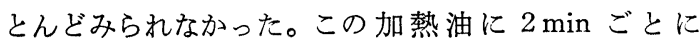
$0.035 \mathrm{~g}$ の水を滴下（これが全部油に溶けると $1750 \mathrm{ppm}$

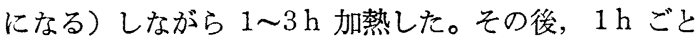
に油 $5 \mathrm{~g}$ をとり出して溶存水量及び酸価の分析試料とし た。

また，サフラワー油 $(20 \mathrm{~g})$ ，上記鉄板 12 枚及びガラ スウール $(1 \mathrm{~g})$ を入れた場合についても上記と同様の条 件で水を滴下しながら加熱した。その後， $1 \mathrm{~h}$ ごとに油 $5 \mathrm{~g}$ 及び鉄板 3 枚をとり出して，溶存水量，酸価，鉄の 溶出量及び鉄板の表面状態の分析試料とした。なお，溶 存水量は $2 \cdot 1 \cdot 1$ に示した水分計を使用した。溶存水量, 酸価の測定結果を Table-2 に示した。

油中からとり出した鉄板は測定する前に室温で別々に

Table-2 The relation among dissolved water, dissolved iron and $\mathrm{AV}$ of the oil in safflower oil con= tained the iron plate at $180^{\circ} \mathrm{C}$.

\begin{tabular}{c|ccc|c|c}
\hline \multirow{2}{*}{$\begin{array}{c}\text { Heating } \\
\text { time }\end{array}$} & \multicolumn{4}{|c}{ States of reaction } \\
\cline { 2 - 6 }$(\mathrm{h})$ & $\begin{array}{c}\mathrm{O} \text { il }-\mathrm{H}_{2} \mathrm{O}^{1)} \\
\mathrm{H}_{2} \mathrm{O}\end{array}$ & $\mathrm{A} \mathrm{V}$ & $\begin{array}{c}\mathrm{H}_{2} \mathrm{O} \\
(\mathrm{ppm})\end{array}$ & $\mathrm{AV}$ & $\begin{array}{c}\mathrm{Fe} \\
(\mathrm{ppm})\end{array}$ \\
\hline 0 & 226 & 0.60 & 230 & 0.60 & 0.48 \\
1 & 518 & 0.89 & 580 & 1.49 & 0.60 \\
2 & 827 & 1.06 & 935 & 2.21 & 1.10 \\
3 & 1012 & 1.27 & 1168 & 2.53 & 1.71 \\
\hline
\end{tabular}

1) Oil-Dissolved water

2) Oil-Dissolved water-Iron plate

Detector temp. : $260^{\circ} \mathrm{C}$

Injector temp.: $260^{\circ} \mathrm{C}$

Carrier gas: $\mathrm{N}_{2}, 80 \mathrm{ml} / \mathrm{min}$.

用意した $20 \mathrm{ml}$ のエーテル中でかくはんしながらおの おの $3 \mathrm{~min}$ 洗浄した。その後, 室温で $10^{-6} \mathrm{mmHg} の$ 減圧下で約 $60 \mathrm{~min}$ 乾燥した後, $2 \cdot 1 \cdot 2$ と同じ方法で表 面分析を行った。その結果を Fig.-2 に示した。

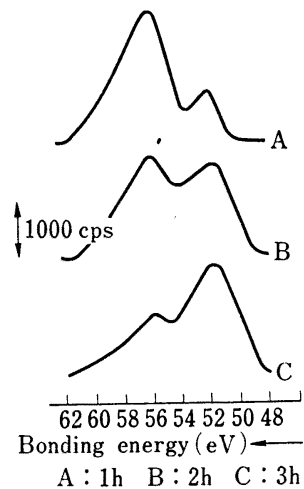

Fig.-2 ESCA spectra of $\mathrm{Fe}_{3 \mathrm{p}}$ of iron and iron oxides on the surface of the iron plate in safflower oil contained water at $180^{\circ} \mathrm{C}$ for $1 \sim 3 \mathrm{~h}$.

\section{$2 \cdot 3$ 実験中に生じたカルボン酸へ溶解した水の定量}

サフラワー油中には加水分解で生成したカルボン酸が 含まれるが，このカルボン酸が水を溶解する。それゆ え，溶存水量を定量するための検量線をうる目的でつぎ の実験を行った。

サフラワー油の代わりに流動パラフィン(和光純薬製： $215 \sim 220^{\circ} \mathrm{C} / 1 \mathrm{mmHg}$ で蒸留精製したもの）を用いて， これにウンデカン酸 (東京化成製 : $141 \sim 2^{\circ} \mathrm{C} / 0.7 \mathrm{mmHg}$ で蒸留精製したもの，純度 $99 \%$ 以上）を $0.99 \%(\mathrm{AV}$ に換算して 2.77), 2.58\% (7.23), 4.03\% (11.30) 添加 したもの及び比較試料として流動パラフィンのみをおの おの $20 \mathrm{~g}$ ずつ調製し, 2.2 と同様の条件で水を滴下しな がら 1 3h 加熱した。その後, $1 \mathrm{~h}$ ごとに各試料を $5 \mathrm{~g}$ ずつ採取して溶存水量を測定した。 $\mathrm{AV}$ と溶存水量との 関係を Fig.-3 に示した。これを検量線としてカルボン 酸に溶解した水分量を定量した。

\section{4 サフラワー油中の鉄の溶出量の測定}

$2 \cdot 2$ で得られたサフラワー油中の鉄の溶出量は原子吸 


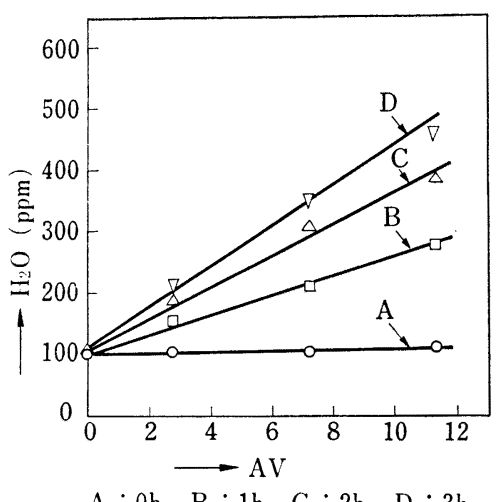

Fig.-3 The relation between acid values and dissolved water in the paraffinic oil contained undecanoic acid at $180^{\circ} \mathrm{C}$ for $1 \sim 3 \mathrm{~h}$.

光光度計（日立製 170-50 A) で分析した。すなわち， 試料約 $2 \mathrm{~g}$ を正確に測りとり，これを湿式灰化法で灰化 し，これに塩酸及び過塩素酸をおのおの $1 \mathrm{ml}$ を加えて 熱板上で白煙が発生するまで加熱した。放冷後, 水を加 えて $50 \mathrm{ml}$ 定容として, この溶液を原子吸光光度法 (測 定波長 $248.3 \mu \mathrm{m}$ ）で分析した。測定は 3 回行い，その 平均值を分析值とした。その標準偏差值は 0.14 であっ た。これらの結果を Table-2 に示した。

\section{3 結果及び考察}

\section{1 加熱サフラワー油の溶存水について (油-水系)}

\section{$3 \cdot 1 \cdot 1$ 溶存水量の経時変化}

$5^{\circ} \mathrm{C}$ に約 6 か月保存したサフラワー油（溶存水量 226 $\mathrm{ppm}, \mathrm{POV} 0.8$, この油を以下基準油とする) を $180^{\circ} \mathrm{C}$ に加熱し，これに水を $2 \mathrm{~min}$ ごとに $0.035 \mathrm{~g}$ 滴下した とき, 加熱時間 $0 \sim 2 \mathrm{~h}$ の間は溶存水量がほぼ直線的に 増加（単位時間当たりの水の溶解量は $8.30 \times 10^{-2} \mathrm{ppm} /$ s）しているが，3h ではその増加率は低下した（Fig.-4 のB線)。

$1 \mathrm{~h}$ 加熱後の水分量注基準油の 2.3 倍, $2 \mathrm{~h}$ 後は 3.7 倍及び $3 \mathrm{~h}$ 後は 4.5 倍であった。

$3 \cdot 1 \cdot 2$ 加水分解で生じたカルボン酸に 溶存する水分 量

この油一水系で加水分解されて生じたカルボン酸が 溶 存水量にどのように影響を与えたかを検討した。AV と 加熱時間との関倸を Fig.-5 のA線汇示した。

これによると，1 3h では $\mathrm{AV}$ がほぼ直線的に増加 (単位時間当たりの $\mathrm{AV}$ の増加率は $6.20 \times 10^{-5} \mathrm{AV} / \mathrm{s}$ ) した。これらの生成したカルボン酸が水を溶解させる原 因になると考えられるので，2.3 の方法で得たカルボン 酸溶解する水分量の検量線 (Fig.-3) を用いて, 油-

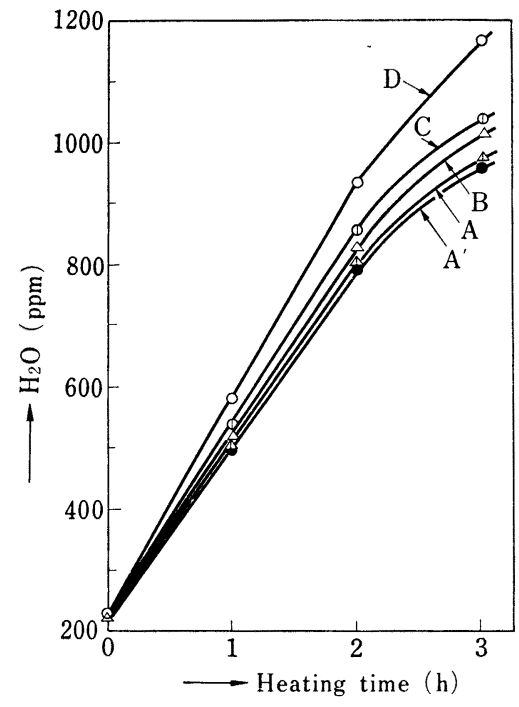

A : Safflower oil

$\mathrm{A}^{\prime}$ : Safflower oil contained the iron plate

B : Fatty acid hydrolyzed by dissolved water, plus A

C : Fatty acid hydrolyzed by catalyzing action of the iron, plus B

$\mathrm{D}:$ Adsorbed water on the surface of the iron plate, plus $\mathrm{C}$

Fig.-4 The distribution amounts of the dissolved water among the fatty acid, the iron plate and the oil in safflower oil at $180^{\circ} \mathrm{C}$ for $1 \sim 3 \mathrm{~h}$.

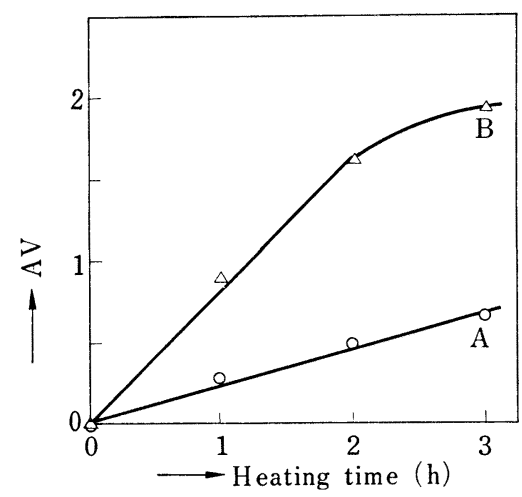

A : Safflower oil

B : Safflower oil contained the iron plate

Fig.-5 The relation between acid value and heating time of safflower oil, and that contained the iron plate at $180^{\circ} \mathrm{C}$

水系で生じたカルボン酸に溶存する水分量を計算した。 加熱前の油の AV は 0.60 であるから，これに対する 溶存水量は $0.4 \mathrm{ppm}$ であり, 同様にして $1 \mathrm{~h}$ 加熱した 油では $15 \mathrm{ppm}, 2 \mathrm{~h}$ では $26 \mathrm{ppm}, 3 \mathrm{~h}$ では $38 \mathrm{ppm}$ で 
あった。Fig.-4のB線に示した溶存水量は油-水系の全 溶存水量であるので, 上記で計算した試料及び加水分解 で生じたカルボン酸による溶存水量を差し引くとサフラ ワー油のみの溶存水量が算出できる。Fig. -4 のA線に それを示した。

Fig.-4 の A, B 線より,この系のサフラワー油と生 じたカルボン酸に対する溶存水量の割合が計算できる。 これらの割合と加熱時間との関係を Fig.-6のA及び $\mathbf{A}^{\prime}$ 線に示した。これによると, 溶存水量によって加水 分解したカルボン酸に溶解した水分量は 1.2 1.6\% で あった。

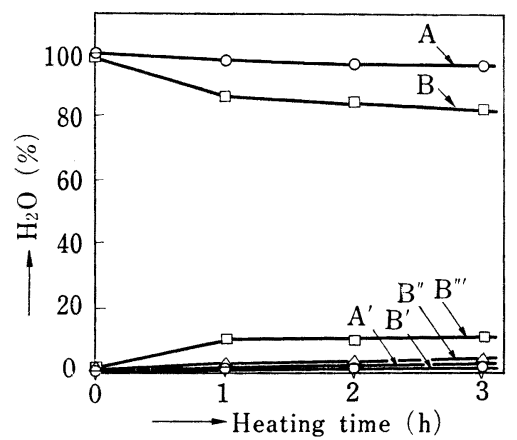

A : Safflower oil

B : Safflower oil contained the iron plate

$\mathrm{A}^{\prime}$ : Fatty acid hydrolyzed by dissolved water in safflower oil

$\mathrm{B}^{\prime}$ : Fatty acid hydrolyzed by dissolved water in safflower oil contained the iron plate

$\mathrm{B}^{\prime \prime}$ : Fatty acid hydrolyzed by catalyzing action of the iron in safflower oil contained the iron plate

$\mathrm{B}^{\prime \prime \prime}$ : Adsorbed water on the surface of the iron plate

Fig.-6 The relation between distribution ratios of dissolved water and heating time to the fatty acid, the iron plate and the oil in safflower oil at $180^{\circ} \mathrm{C}$ for $1 \sim 3 \mathrm{~h}$.

3・1.3 加水分解されなかった油とそれに溶解した水 のモル比について

溶存水によって油が加水分解されるので, 油の AV を用いて加水分解で生じたカルボン酸の当量数を計算 し，その $1 / 3$ 当量が油の 1 分子に相当するとして（油の 平均分子量を 874.3 とした。ただし, Table-1 に示し た油の脂肪酸組成上り算出), 加水分解された 油の量を 計算し，それより，油一水系の加水分解されなかった油 のモル数とその油にとけた溶存水量との関係を Fig.-7 に示した。これによると, $1 \sim 3 \mathrm{~h}$ 加熱した場合, これ らの油のモル数が $2.285 \sim 2.280 \times 10^{-2} \mathrm{~mol}$ に変化し, その油にとけた水分量は 503 974 ppm にほぼ直線的に 増加している。

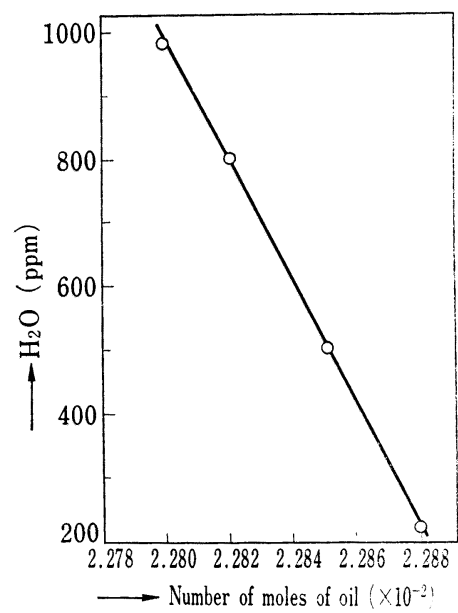

Fig. -7 The relation between the number of moles of safflower oil and the amount of the dissolved water.

\section{2 鉄板が共存した加熱サフラワー油の 溶存水量に つて (油-鉄-水系)}

\section{$3 \cdot 2 \cdot 1$ 溶存水量の経時変化}

基準油に鉄板を入れた試料（水分量 $230 \mathrm{ppm}$ )を油一 水系のときと同様の条件で加熟した場合，溶存水量注 油一水系の場合と異なり，その経時変化は直線性を示さ なかった。しかし，油-水系の溶存水量と各加熱時間ご とに比較すると, 約 1.1〜1.2 倍増加した（Fig.-4の D線)。加熱時間 $0 \mathrm{~h}$ の油の水分量を基準にすると, $1 \mathrm{~h}$ 加熱した油の溶存水量は約 2.6 倍, $2 \mathrm{~h}$ では 4.1 倍,

$3 \mathrm{~h}$ では 5.1 倍であった。

$3 \cdot 2 \cdot 2$ 加水分解で生じたカルボン酸に 溶存する水分 量について

油-鉄-水系で加水分解で生じたカルボン酸と溶存水量 との関係を検討した。AV と加熱時間との関係を Fig.5 のB線に示した。これによると，1２h 加熱すると， $\mathrm{AV}$ が直線的に増加した。単位時間当たりの AV の増 加率は $2.24 \times 10^{-4} \mathrm{AV} / \mathrm{s}$ であり，これは油一水系のそれ と比べ約 3.6 倍大きかった。しかし， $3 \mathrm{~h}$ 加熱した場 合, $\mathrm{AV}$ は 1.93 で $2 \mathrm{~h}$ 以前の増加率より低下した。 この系の各油の AV はこのように油-水系のそれより大 きいが，これは共存する鉄板が油の加水分解の触媒とし て働いたためと考えられる。これら生成したカルボン酸 に溶解した水分量は油-水系で述べたと同様の方法で求 めた。これによると，1 $\mathrm{h}$ 加熱した油では $15 \mathrm{ppm}, 2 \mathrm{~h}$ では $39 \mathrm{ppm}$ 及び $3 \mathrm{~h}$ では $54 \mathrm{ppm}$ である。これらの 溶存水量は溶存水及び鉄板の触媒作用で加水分解して生 成したカルボン酸に溶解したものであると考えられる。 それ沛え, 油-鉄-水系に存在するカルボン酸の溶存水量 から油-水系に存在するカルボン酸の溶存水量を差し引 
くことによって鉄が加水分解したカルボン酸の溶存水量 が算出できると考えられる。その結果, この系の鉄触媒 によって生じたカルボン酸にとけた水分量は $1 \mathrm{~h}$ 後 9 $\mathrm{ppm}, 2 \mathrm{~h}$ 後 $26 \mathrm{ppm}, 3 \mathrm{~h}$ 後 $38 \mathrm{ppm}$ となった。これら を油一水系のカルボン酸に溶解した水分量と比較すると 約 1.5 倍 ( $1 \mathrm{~h}$ 加熱の場合) 2.4 倍 ( $3 \mathrm{~h}$ 加熱の場合) であった。

$2 \cdot 2 \cdot 3$ 加水分解されなかった油に 溶存する 水分量に ついて

$3 \cdot 2 \cdot 2$ で述べたように鉄によって加水分解がさらに進 むため油の量が油一水系に比べて少なくなるので, 油一水 系の場合と同様の方法で補正を行った。

たとえば， $1 \mathrm{~h}$ 加熱後の油において，加水分解しない 油のモル数は $2.277 \times 10^{-2} \mathrm{~mol}$ である。加熱時間 2 及び $3 \mathrm{~h}$ についても同様の方法で算出し，それぞれ $2.269 \times$ $10^{-2}$ 及び $2.265 \times 10^{-2} \mathrm{~mol}$ を得た。これらの油の溶存 水量を計算するため, 油一水系の加水分解しない油の 1 mol 当たりの溶存水量を基準 (Fig.-7) にして（加熱時 間 1,2 及び $3 \mathrm{~h}$ について), 上記の油-鉄-水系の加水 分解しない油の溶存水量を算出し Fig.-3 の $\mathbf{A}^{\prime}$ 線に 示した。これによると, $1 \mathrm{~h}$ 加熱した場合は $501 \mathrm{ppm}$, $2 \mathrm{~h}$ では $796 \mathrm{ppm}$ 及び $3 \mathrm{~h}$ では $967 \mathrm{ppm}$ であった。

$3 \cdot 2 \cdot 4$ 溶存水量と鉄板との関係について

油-鉄-水系の溶存水量は加水分解されない油, 加水分 解で生じたカルボン酸（溶存水及び鉄によるもの）及び 試料油に含まれるカルボン酸以外に鉄板の周辺に集まっ た水も存在すると考えられる。それゆえ，油-鉄-水系の 溶存水量-加熱時間曲線 (Fig.-4 のD線) より上記の影 響を差し引くと Fig. -4 のC線をうる。 4 の D曲線と 4

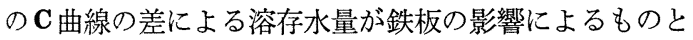
考えられる。これらより，加熱時間 $0 \mathrm{~h}$ では $4 \mathrm{ppm}$, $1 \mathrm{~h}$ では $55 \mathrm{ppm}, 2 \mathrm{~h}$ では $87 \mathrm{ppm}$ 及び $3 \mathrm{~h}$ では 125 ppm であった。

$3 \cdot 2 \cdot 5$ 油-鉄-水系における溶存水量の分布について 油-鉄-水系において，油中に溶解した水分量の内，油 自体へ溶解した水分量, 溶存水及び鉄によって加水分解 したカルボン酸に溶解したと考えられる水分量及び鉄板 自体が呼びこんだ水分量の各割合を求めた（Fig.-6の $\mathbf{B}, \mathbf{B}^{\prime}$ 及び $\left.\mathbf{B}^{\prime \prime}\right)$ 。これによると, 油だけに溶解した水 分量は 1 3 h 加熱した場合は 86.3 82.8\%であっ た。溶存水の存在によって生成したカルボン酸に溶解し た水分量は $1.0 \%$ (加熱時間 $1 \mathrm{~h}$ ) 1.4\%（3h），鉄の 存在によって生成したカルボン酸に溶解した水分量は 1.6\% (1 h) 3.3\% (3h)，鉄周辺潗まった水分量は 9.4\% ( $1 \mathrm{~h}) \sim 10.7 \%$ ( $3 \mathrm{~h})$ であった。

\section{3 鉄の溶出過程における鉄板の 表面の 組成变化に つて}

油-鉄-水系で使用した鉄板の表面状態を ESCA を用
いて測定した。この鉄板を $2 \cdot 2$ の条件で $1,2,3 \mathrm{~h}$ 加 熱し，それぞれ試料をサンプリングし鉄の表面を ESCA で分析（Fig.-2）して基準の鉄板と比較しその変化を検 討した。基準の鉄板の ESCA スペクトルを Fig.-1 に 示した。これによると結合エネルギー $52 \mathrm{eV} に \mathrm{Fe}_{3 \mathrm{p}}$, $56 \mathrm{eV}$ にその酸化物のピークが見られた。これら酸化物 には $\mathrm{Fe}_{2} \mathrm{O}_{3}$ (結合エネルギー $\left.\left.55.7 \mathrm{eV}\right)^{4}\right), \mathrm{Fe}_{3} \mathrm{O}_{4}(56.0$ $\mathrm{eV})^{4)}$ 及び含水酸化鉄 $\mathrm{FeOOH}(56.0 \mathrm{eV})^{4)}$ 等が含まれ ていると考えられる。また，金属鉄のピークは $52 \mathrm{eV}$ にでている4)。

以上の結果からこれらのピーク面積を比較すると鉄と 酸化物の割合は $15: 85$ となり, 表面層から約 $40 \AA$ (ESCA の標準測定の深さ) の範囲では酸化物層がみら れた。

これと同様の方法で加熱油中からサンプリングした鉄 板についても ESCA で分析した (Fig.-2)。これらか ら鉄板の表面の酸化物と金属鉄面のピーク面積（半值幅 法）の割合を算出した。これによると，加熱前の鉄板表 面の酸化物のしめる割合は $84.9 \%$ であるのに対し，油 中で水を滴下しながら $1 \mathrm{~h}$ 加熱した鉄板のそれは 81.2 $\%$ ，同様に $2 \mathrm{~h}$ では $51.6 \%, 3 \mathrm{~h}$ では $33.9 \%$ となっ た。鉄が水に溶解する場合, 通常鉄が酸化物を経て溶解 すると言われているが，油中の溶存水に鉄が溶解する場 合についても同様のことが考えられる。ESCA で求め た各試料の酸化物のパーセントと原子吸光で求めた油中 に溶出した鉄の量との経時変化を Fig.-8 に示した。

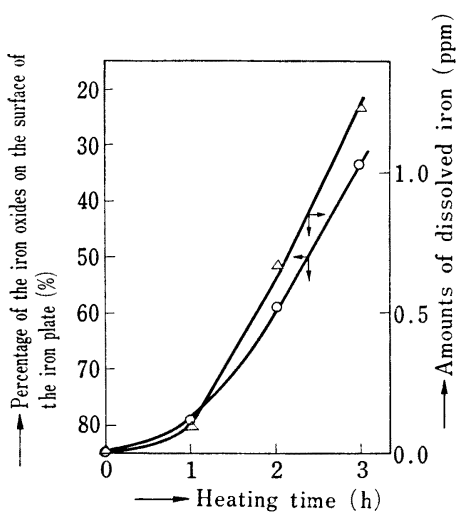

Fig. -8 The relation among the percentage of iron oxides on the surface of the iron plate and the amounts of the dissolved iron from that plate in the safflower oil, and heating time at $180^{\circ} \mathrm{C}$ by the methods of ESCA and atomic absorption spectrometry.

これによると，鉄の溶出量が $1 \mathrm{~h}$ 加熱では $0.12 \mathrm{ppm}$ であるのに対して，2h では $0.62 \mathrm{ppm}$ (1 h のときの 約 5.2 倍), $3 \mathrm{~h}$ では $1.23 \mathrm{ppm}$ (10.3 倍) となるが, 
同時に, ESCA で分析した鉄表面の酸化物の割合がほ ぼ同じ傾向を示した。このことから, 原子吸光で求めた 鉄の溶出量と ESCA で求めた酸化物に相関性があるこ とがわかった。

それゆえ, 油の中に鉄が溶解する場合, 鉄板表面の酸 化物が油中の溶存水に溶解していくものと考えられる。 油中に金属が溶出する原因は油中の溶存水であることを 先に報告したが2 ${ }^{2,3)}$, 本報では主に鉄の酸化物層の周辺 に集まった水によって鉄表面の酸化物が溶出され油中に 拡散されていくと考えられる。

\section{4 ま と め}

1）サフラワー油を $180^{\circ} \mathrm{C}$ に加熱し，水を $0.018 \mathrm{~g} / \mathrm{min}$ の割合で滴下しながら $1,2,3 \mathrm{~h}$ 加熱した(油-水系)。 溶存水量は 518，827 及び $1012 \mathrm{ppm}$ であった。

2）鉄板を入れたサフラワー油を 1）と同じ条件で水を 滴下しながら加熱した（油-鉄-水系）。溶存水量は 580，935 及び $1168 \mathrm{ppm}$ であった。

3）油一水系における溶存水の分布は油中に 97.1 96.2 $\%(1 \sim 3 \mathrm{~h})$, 試料中に含まれるカルボン酸及び加水分 解で生じたカルボン酸には 2.9 3.8\% (1〜3h) であ った。
4）油-鉄-水系に抢ける溶存水の分布は油中に 86.3 $82.8 \%(1 \sim 3 \mathrm{~h})$, 試料中に含まれるカルボン酸及び加 水分解で生じたカルボン酸には $4.2 \sim 6.6 \%$ (1 3 h $)$, 鉄板周辺に集まったと考えられる溶存水は 9.4 10.7 \% (1 3h) であった。

5）油-鉄-水系における鉄板の表面は ESCA の分析に よると鉄の酸化物層が 81.2 33.9\%(1 3h) に減少 した。それに従って油中の鉄の 溶出量が $0.12 \sim 1.23$ ppm (1 3h) に増加した。

6）以上の結果より，サフラワー油隹鉄板を入れて 180 ${ }^{\circ} \mathrm{C}$ に加熱し，水を加えたとき，溶存水の 9.4 10.7\% は鉄板の周辺潗まる。鉄板表面をおおっている酸化 物層 (85\%) から周辺集まっている水を通して鉄が 油中へ溶出することがわかった。

(昭和 57 年 12 月 15 日受理)

\section{文献}

1）梶本五郎, 吉田弘美, 油化学, 20, 811 (1971)

2) 高砂子昌久, 高岡 京, 油化学, 30, 558 (1981)

3）高砂子昌久, 高岡 京, 油化学, 31, 167 (1982)

4) N.S. McIntyre, D.G. Zetruk, Anal. Chem., 49, 1521 (1977); C.S. Fadley, D.A. Shirley, Phys. and Chem., 74 A， 543 (1970); 橋本功二, 浅見勝彦，防食技術，26， 375 (1977) 